\title{
Article \\ Environmental Factor Accelerate the Deterioration of Tuff Stone Heritage: A Case Study of a Stone House in Southeast China
}

\author{
Yang $\mathrm{Wu}^{1}$, Jian Shen ${ }^{2}$, Jianchao Zhang ${ }^{3}$ and Bingjian Zhang ${ }^{1,4, *}$ \\ 1 School of Art and Archaeology, Zhejiang University, Hangzhou 310028, China; 11804061@zju.edu.cn \\ 2 Social Affairs Committee of Xiling Seal Engraver's Society, Hangzhou 310014, China; 18200291933@163.com \\ 3 School of Earth Science, Zhejiang University, Hangzhou 310027, China; zhangjianchao@zju.edu.cn \\ 4 Department of Chemistry, Zhejiang University, Hangzhou 310027, China \\ * Correspondence: zhangbiji@zju.edu.cn; Tel.: +86-0571-87997523
}

check for updates

Citation: Wu, Y.; Shen, J.; Zhang, J.; Zhang, B. Environmental Factor Accelerate the Deterioration of Tuff Stone Heritage: A Case Study of a Stone House in Southeast China. Buildings 2022, 12, 188. https:// doi.org/10.3390/buildings12020188

Academic Editor: Humberto Varum

Received: 14 December 2021

Accepted: 1 February 2022

Published: 7 February 2022

Publisher's Note: MDPI stays neutral with regard to jurisdictional claims in published maps and institutional affiliations.

Copyright: (c) 2022 by the authors. Licensee MDPI, Basel, Switzerland. This article is an open access article distributed under the terms and conditions of the Creative Commons Attribution (CC BY) license (https:// creativecommons.org/licenses/by/ $4.0 /)$.

\begin{abstract}
Water plays an important role in the deterioration of rocks. Often, the condensation cannot be ignored in addition to the rain and seepage, especially for stone relics built with tuff in humid areas. As part of this study, a century-old stone house in southeastern China was investigated alongside the microclimate, including temperature, humidity, and rainfall in the study area. Results showed that the main types of deterioration in this house were detachment, with some areas exhibiting surface hardness decreased by more than $50 \%$. This decay was caused in part by condensation on the inner walls of the stone house during the rainy season. According to statistics, more than two-thirds of the time the rainy season produces condensate on the inner wall, which is primarily found on the north side of the house because there is less solar radiation. Conversely, the stress caused by severe temperature differences on the south side contributes more to the deterioration of rock. Environmental conditions with high humidity and strong temperature differences will accelerate the deterioration process of tuff stone with high porosity. Consequently, it is recommended that stones built by tuff in such a humid environment take rainproof measures and maintain good air circulation to reduce the adverse effects of condensation.
\end{abstract}

Keywords: environmental monitoring; tuff; temperature difference; stone heritage

\section{Introduction}

Stone relics are an important cultural heritage component that must be preserved for future generations. Due to their direct exposure to the natural environment, they are affected by solar radiation, water, wind, and other climate factors [1,2]. Among these, water plays a key role, especially for rocks with high porosity [3-7].

There are four ways that water accelerate the deterioration of stone. First is mechanical scouring-because water has kinetic energy-which can scour the rock surface and remove generated rock particles $[8,9]$. Second is chemical dissolution-soluble minerals in rocks are gradually dissolved by water and run off, and if the $\mathrm{pH}$ value of the water is low, such as in the case of acid rain, its destructive effect is more significant, especially for carbonate rocks $[10,11]$. The third is the damage caused by volume expansion after water absorption. In those rocks containing a large amount of clay minerals, such as montmorillonite, significant volume expansion will occur after water absorption, resulting in many small cracks which destroy the integrity of rock. The long-term dry-wet cycle and freeze-thaw cycle will accelerate the destruction of rock by expansion force $[6,12,13]$. Lastly, water also causes the bio-deterioration of rocks because water provides suitable conditions for the growth of plants, fungal, bacterial, lichen, or insect colonies. Their roots cause physical damage to the rock, and the acids produced by their metabolism cause chemical damage at the same time $[14,15]$.These destructive effects will not only change the rock's surface morphology, but also change its physical and mechanical properties. Such changes can be reflected by a series of tests conducted by some nondestructive testing equipment such as 
color difference meter, surface hardness meter, and some portable spectrometers. For the moisture content in the stone relics, electrical methods, infrared thermography, portable nuclear magnetic resonance, as well as radar and microwave moisture measurements are commonly used [16-19].

Precipitation, seepage, and condensation of water vapor in the air are three possible sources of water in stone relics. Over the last decade, many advanced automatic monitoring devices are used to monitor the microenvironment of the stony heritage sites; numerous studies have investigated how cultural relics are damaged by factors including rainfall intensity, frequency, the acidity of rainwater, and the combined effects of rainfall and temperature difference [11,20-22]. Meanwhile, regarding wild stone heritage, such as the Mogao Grottoes and the Leshan Giant Buddha, many studies have conducted to determine the water seepage path and to select better grouting materials to seal the cracks and reduce the risk of water to the safety of the stone relics [23-25]. However, the influence of condensates was often overlooked by researchers. Nevertheless, condensation water is a major factor in causing damage to heritage buildings such as museums, churches, caves, and so on, especially in high-humidity areas with frequent temperature changes [26-29]. According to the results obtained by CAMUFFO [30], on clear nights, the condensation on building structures facing the sky may reach $0.2 \mathrm{~kg} / \mathrm{m}^{2}$, and the maximum amount of water condensed occurs in the autumn. Yang and Fang [31] developed a device to monitor and study condensation in the Longmen Grottoes; their results indicated that condensation occurs from May to September each year, and the weight of the water can exceed $100 \mathrm{~kg}$. Together with the dissolution of carbon dioxide, this has a significant impact on the erosion of the stone sculptures.

Condensed water will form on the wall surface when wet air meets a wall whose temperature is below its dew point $[28,29,32]$. There are two prerequisites to forming condensate: one is high humidity, which provides a source of water, and the other is a large temperature difference. Both conditions can be met during the rainy season in southeastern China, since in the subtropical monsoon climate zone, the humid air will stop along the Yangtze River when warm air blowing from the south meets cold air from the north pole, resulting in high temperatures and humidity in the region [33,34]. During this period, condensate was easily formed in caves, tombs, and indoor spaces with rapid temperature changes. However, as of now, there is still a lack of research on the damage caused by condensation to stone artifacts in the region. Therefore, this paper used a stone house built 100 years ago as an example. Site disease investigation and micro environmental monitoring were conducted to analyze the characteristics of condensation generation and to evaluate the effect of condensation on the deterioration effect of this tuff stone artifact, which could provide a useful reference for the future conservation of stone artifacts in humid environments.

\section{Site Description}

Xiling Seal Engraver's Society $\left(30^{\circ} 15^{\prime} 3.6^{\prime \prime} \mathrm{N}, 120^{\circ} 08^{\prime} 24^{\prime \prime} \mathrm{E}\right)$ is located in the southern root of Gushan beside the West Lake in Hangzhou, Zhejiang Province. Using the methods of quasi-symmetry and axis offset, it skillfully arranges garden composition elements such as buildings, plants, rockeries, and water bodies on the undulating mountains. As a national key cultural relic protection area, the garden is refined and elegant, and the pavilions are well-proportioned, which expresses the essence of South China landscape design and reflects the aesthetic taste of the traditional Chinese elite. The Sanlao stone chamber is a stone house located in this garden; it was built in 1921 to store a stone tablet of the Han Dynasty (223 A.D), which has important historical value. The shape of the stone chamber imitates houkyouinntou pagoda, with double eaves and spires. Its unique shape makes it of high artistic value, and it should therefore be well preserved. The plane of Xiling Seal Engraver's Society and geographical location of Sanlao stone house can be seen in Figure 1. 


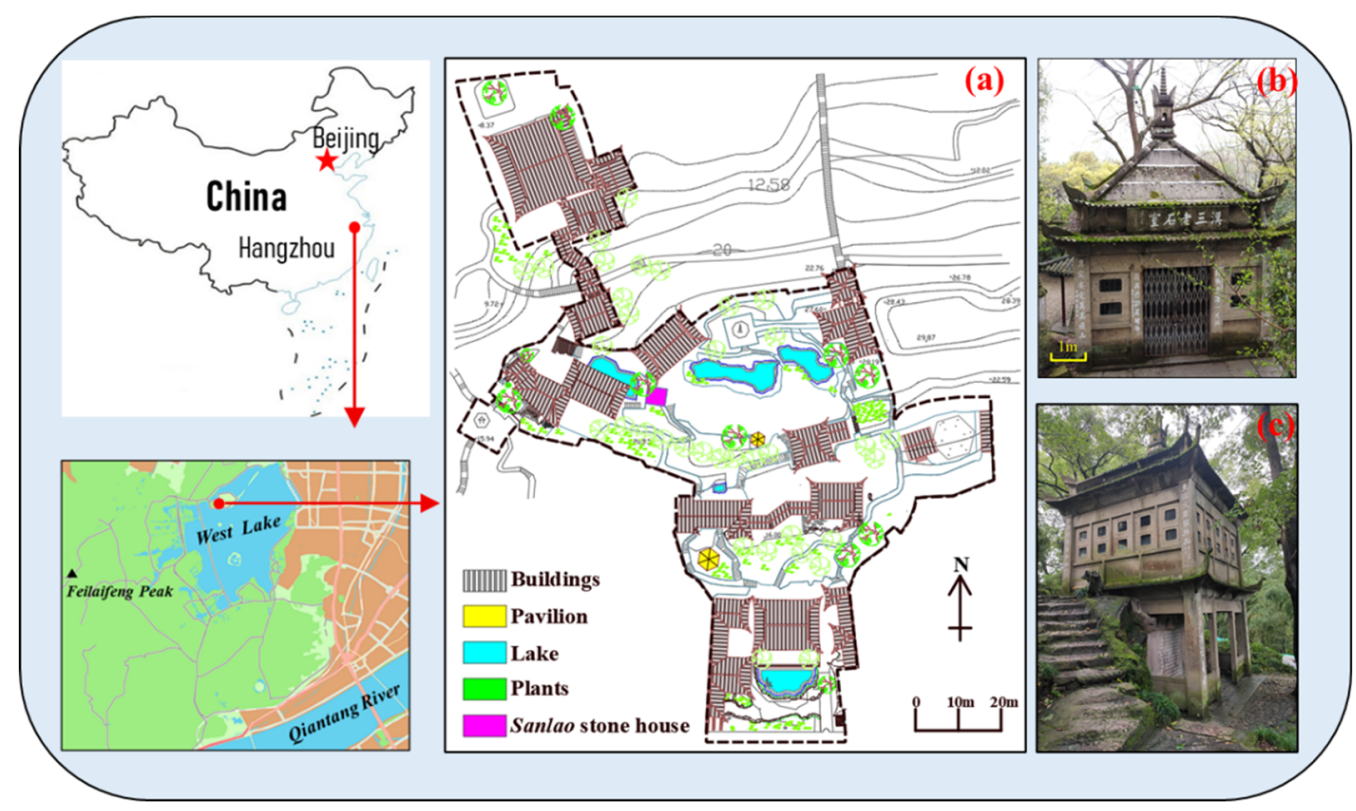

Figure 1. Geographical map of Sanlao stone house. (a) Plan of the Xiling Seal Engraver's Society; (b) Front view of Sanlao stone house; (c) Side view of Sanlao stone house.

\section{Research Method}

\subsection{Rock Properties Analysis}

In this study, two rock samples, one fresh and one weathered, were obtained from the stone house without causing significant damage. Physical properties including density, porosity, water absorption, and mechanical properties of rock samples were tested. It should be noted that because the size of the samples available to us is small, the mechanical properties of the rocks were first tested using a Shore hardness tester to detect the surface strength of the rocks. However, because it has a needle-like probe that will cause damage to the rock surface, we chose a Leeb hardness tester for the subsequent field test. In addition, the rock's mineralogical and petrographic properties were studied using a polarizing optical microscope and scanning electron microscope (SEM-eds). X-ray diffraction analysis was also performed on the fresh and weathered samples to help determine the type of rock and to analyze changes in mineral composition before and after weathering.

\subsection{Deterioration Investigation}

Based on the international standards [35], a detailed disease investigation and a survey of the stone house were carried out using equipment including a rangefinder, digital camera (Nikon D90), and a Leeb hardness meter (Equotip 550 with D-type probe), which is now commonly used to assess the weathering degree of stony relics. Compared with the Schmidt hammer, the impact energy of the Leeb hardness tester is smaller, it is sensitive to the changes in rock strength, and it will not cause damage to stone artifacts. There were 20 values measured on each side of the house for the surface hardness of rocks in four directions, including vertical walls and inclined roofs. As seen is Figure 2, E1, N1, W1 and S1 are located inside the inclined roof of the stone house, and E2, N2, W2 and S2 are located inside the four vertical walls. E, N, W and S represent east, north, west, and south, respectively. Additionally, to quantitatively compare deterioration degrees, this study chose an area (point RP in Figure 2) at the northeast corner outside the stone house to test the hardness of the surface, since it was better preserved than other areas according to the disease investigation and basic strength test results. 


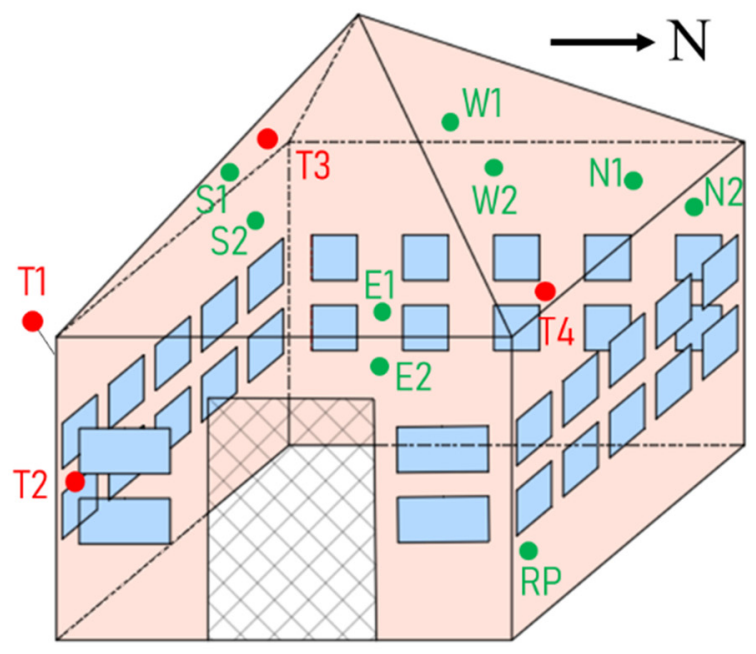

Figure 2. Distribution of detection points.
Environment monitoring point

- Surface hardness test point stone wall glass window iron fence

\subsection{Environmental Monitoring}

This study monitored the environmental conditions including temperature, relative humidity, and rainfall continuously both inside and outside the house and the indoor surface on the north and south walls for 30 days (6 June 2021-5 July 2021). The detector used to obtain temperature, and humidity data was RC-4HC, which was made by Elitech Technology. Its temperature measuring range was from $-30^{\circ} \mathrm{C}$ to $+60^{\circ} \mathrm{C}$, with a resolution of $0.1{ }^{\circ} \mathrm{C}$ and an accuracy of $\pm 0.6^{\circ} \mathrm{C}$; the humidity measuring range was from 0 to $100 \%$ $\mathrm{RH}$, which resolution was $0.1 \% \mathrm{RH}$, and the accuracy was $\pm 3 \% \mathrm{RH}$. The recorder was powered by a CR2450 battery, and the recording interval was set at 30 min in this study. In addition, a tipping bucket rain gauge was installed outside the room to record the rainfall in the study area. The distribution of detectors is shown in Figure 2. T1 is outside the stone house while T2 is inside, T3 is located on the inner surface of the roof on the south side of the stone house, and T4 is located on the inner surface of the roof on the north.

\section{Results and Discussion}

\subsection{Rock Properties}

The physical properties of rock before and after weathering can be seen from Table 1. Obviously, the surface morphology of the rock has changed significantly after weathering, with an uneven surface and microcracks. The density and surface strength of the rock decreased, while the porosity and pore size increased, and it became more sensitive to water as the water absorption has doubled than before. Under the microscope, it can be observed that the surface of the rock sample is gray green, with a tuffaceous texture and block structure. The whole rock is mainly composed of crystal, lithic debris, and volcanic dust. Among them, the crystal mainly contains albite, K-feldspar and quartz, and the particle size is $0.05-1.5 \mathrm{~mm}$. The energy spectrum analysis results show that some feldspars contain a small amount of $\mathrm{Na}$, forming Alkalifeldspar. The content of volcanic dust is about $15-20 \%$, which size is less than $0.01 \mathrm{~mm}$, and the chemical composition is similar to that of K-feldspar. Comprehensive analysis on the rock samples can determine that the stone used to build the house was tuff, its mineralogical and petrographic properties can see in Figure 3. 
Table 1. Physical mechanical properties of rock from Sanlao stone house.

\begin{tabular}{|c|c|c|}
\hline & Fresh Rock & Weathered Rock \\
\hline \multicolumn{3}{|l|}{ Photograph } \\
\hline Surface morphology & $\begin{array}{l}\text { Gray green in color, with } \\
\text { smooth surface }\end{array}$ & $\begin{array}{l}\text { Dark green in color, with uneven } \\
\text { surface and microcracks, which } \\
\text { covered by off-white powder }\end{array}$ \\
\hline Density & $2.18 \mathrm{~g} / \mathrm{cm}^{3}$ & $1.97 \mathrm{~g} / \mathrm{cm}^{3}$ \\
\hline Mean pore radius & $145 \mathrm{~nm}$ & $453 \mathrm{~nm}$ \\
\hline Porosity & $26 \%$ & $39 \%$ \\
\hline Water absorption by weight & $8 \%$ & $15 \%$ \\
\hline Surface strength & $79.5 \mathrm{HD}$ & $43.2 \mathrm{HD}$ \\
\hline
\end{tabular}
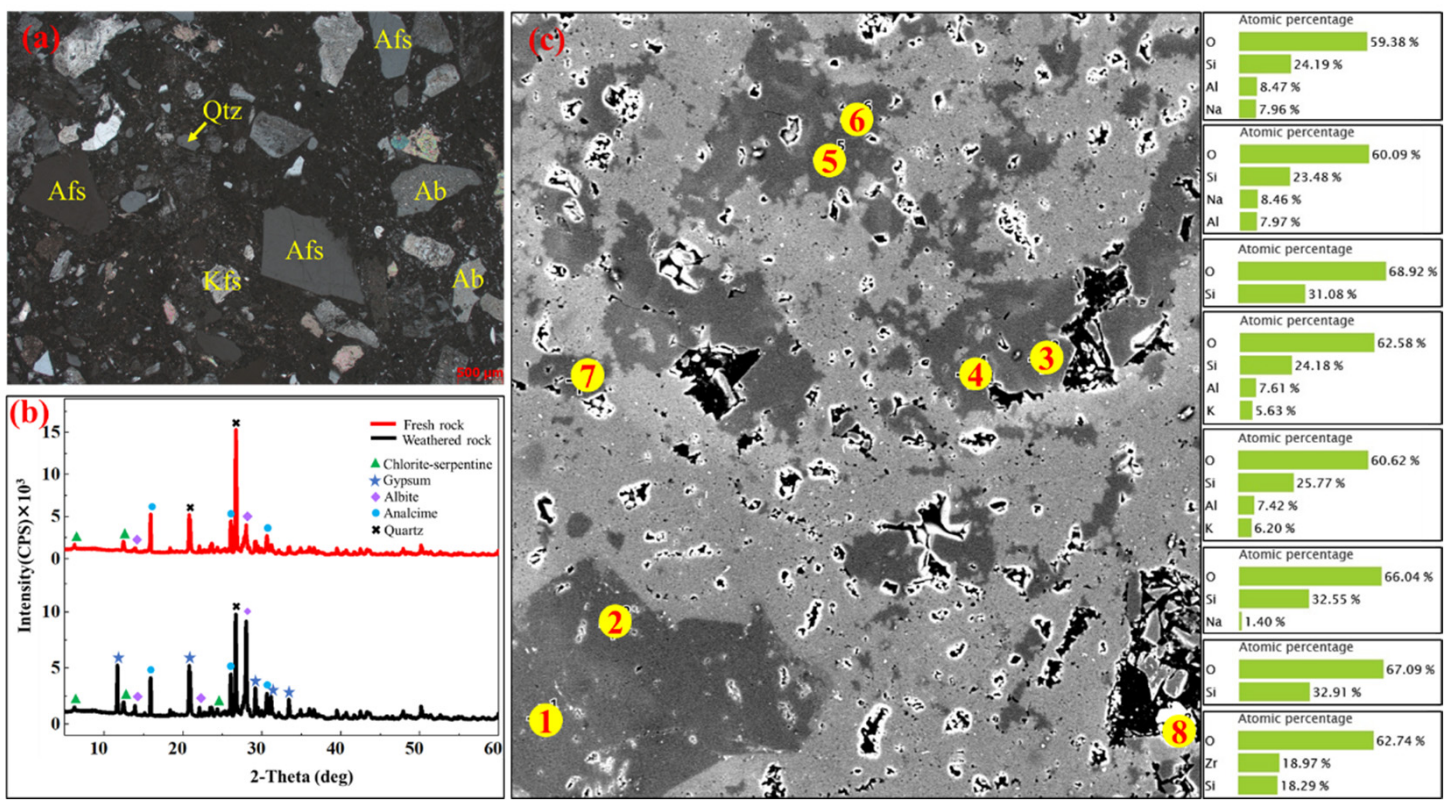

Figure 3. Mineralogical and petrographic properties rock sample from Sanlao stone house. (a) Polarized optical microscopy photograph, Afs is Alkalifeldspar, Kfs is K-feldspar, Qtz is Quartz, Ab is Albite; (b) X-ray diffraction pattern of rock sample; (c) SEM-eds of rock sample, 1 to 8 are the eight points for energy spectrum.

\subsection{Deterioration Characteristics}

Figure 4 shows the deterioration investigation results based on the illustrated glossary of stone deterioration patterns created by the ICOMOS International Scientific Committee for Stone. Since it was considered inappropriate to use a polymer binder that was easy to age but difficult to remove to strengthen stone relics, it was also considered a disease in this study [36]. According to the results, four types of deterioration-contained detachment, biological colonization, improper repair, and discoloration-can be found in this house, and Figure 5 illustrated the areas of each type. The picture showed that detachment, as well as biological colonization, were the main deterioration patterns. Statistics showed that at least 100 square meters of interior wall surface appeared seriously to be pulverized and falling off, which was about $60 \%$ of the wall area, and the deterioration degree in sloping roofs is more severe than it is in vertical walls. In addition, it is noteworthy that the weathering 
varies significantly in the different directions of the stone houses; the weathered area on the west and north sides is much larger than that on the south and east sides. Moss, lichen, and green algae mainly colonized the area near the ground on the north wall. An aerial view of the stone house taken by the UAV showed a dense growth of moss in the west and north of the roof, especially in the west (Figure 4e). It may be related to a tree west of the stone house. In this area, leaves weakened the influence of solar radiation and made the humidity more suitable for moss growth [37]. In this stone chamber, improper repair refers to the black epoxy resin used to fill in the rock gap. These stones were originally used to seal the gap to prevent rainwater infiltration, but today they are seriously deteriorated and fall together with the bonded rock fragments. The eroded surface of this house was caused mainly by the deposition of ions dissolved by water, some of which were orange particles, while others were black crusts and have been confirmed by XRD to be calcium sulfate (seen in Figure 3b).

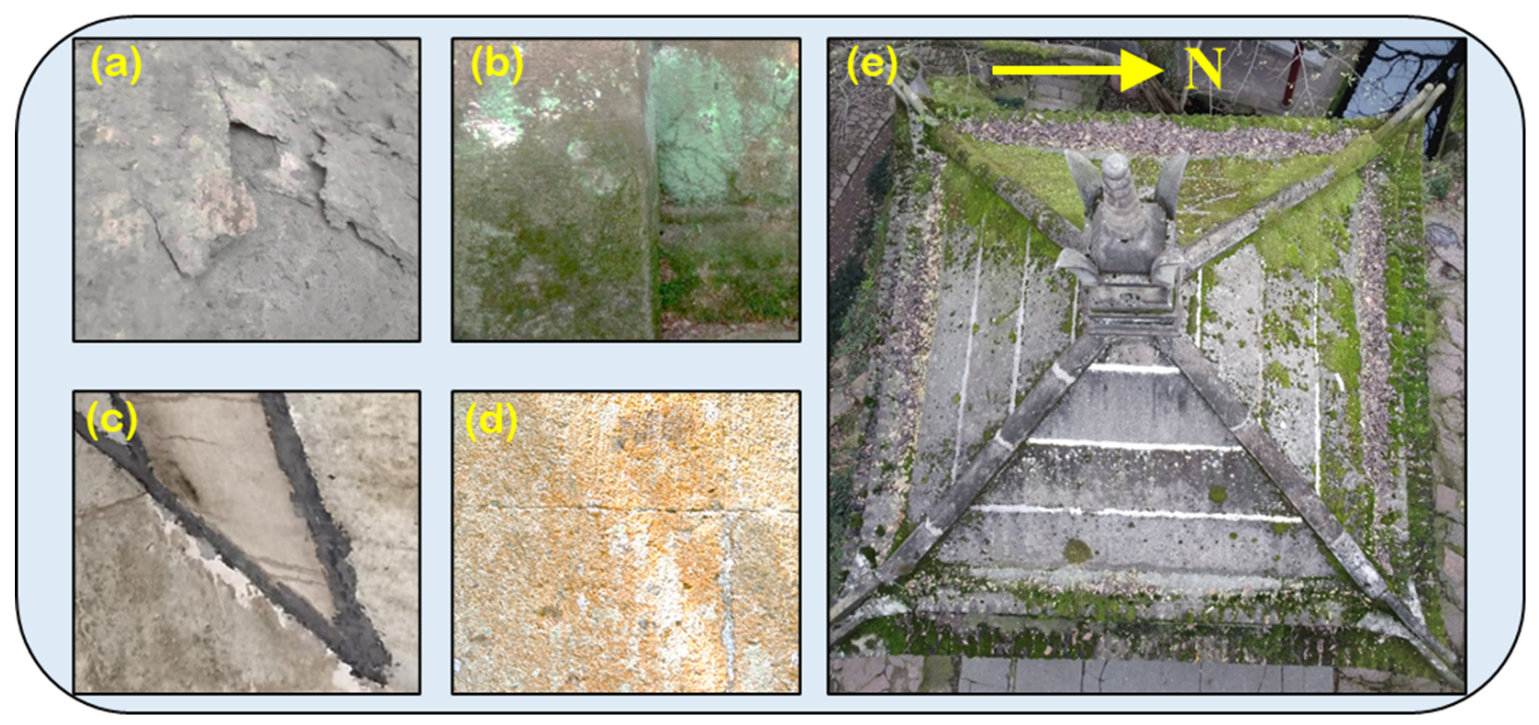

Figure 4. Typical images of surface weathering diseases of the stone house (a) detachment; (b) biological colonization; (c) improper repair; (d) discoloration; (e) top view of the stone house.

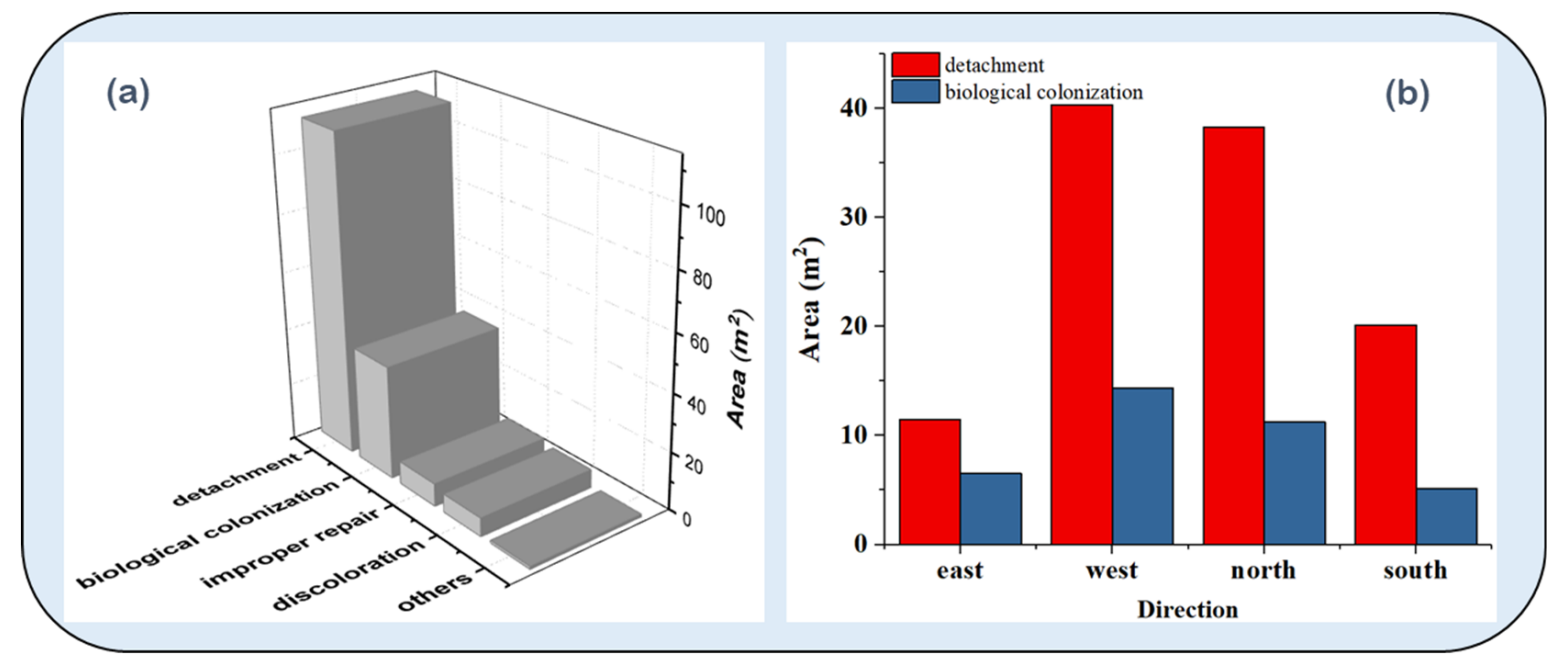

Figure 5. Types and scales of weathering diseases of the stone house. (a) demonstrates the types of weathering diseases; (b) shows the weathering areas of the stone house in different directions.

Surface strength can reflect the degree of deterioration of the rock [38],Figure 6 showed the results of the surface hardness test, which was used to calculate the degree of deteriora- 
tion of the stone. From the figure above, it can be seen that the best-preserved point RP has a surface hardness of $655 \mathrm{HLD}$, while the hardness of the inner wall has dropped to below 500 HLD, a reduction of $23.6 \%$. The hardest part of the roof was on the north side, with a hardness of $340 \mathrm{HLD}, 50 \%$ less than point RP.

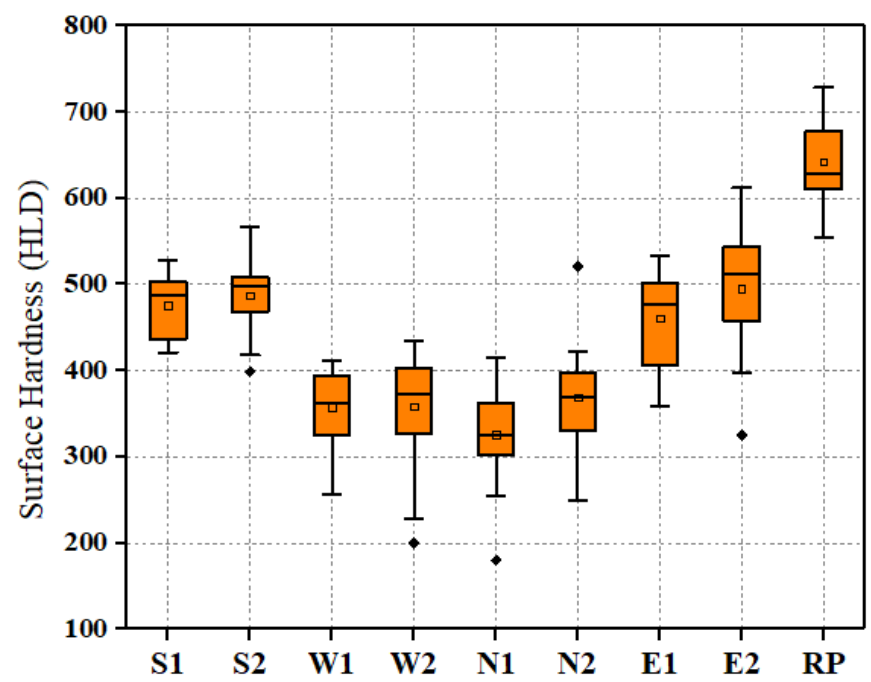

Figure 6. Boxplot of surface hardness value of the stone house.

Furthermore, the hardness values of the north and west walls were lower than those of the east and south walls. The values of S1, S2, E1, and E2 were all around 500HLD, but the values of $\mathrm{W} 1, \mathrm{~W} 2, \mathrm{~N} 1$, and N2 were between 300 and 400HLD, which confirmed the previous disease investigation results. On one side of the stone house, there was also a difference in the hardness of the roof and wall. It may be because the roof was exposed to more solar radiation and rain due to its inclination that it had a lower hardness than the wall.

\subsection{Temperature and Humidity}

According to the monitoring report of the Zhejiang Meteorological Bureau [39], the rainy season in Hangzhou starts on June 10 and ends on July 5 in 2021. As shown in Figure 7, the temperature, humidity, and rainfall of the air inside and outside the stone house were monitored from 6 June to 5 July.

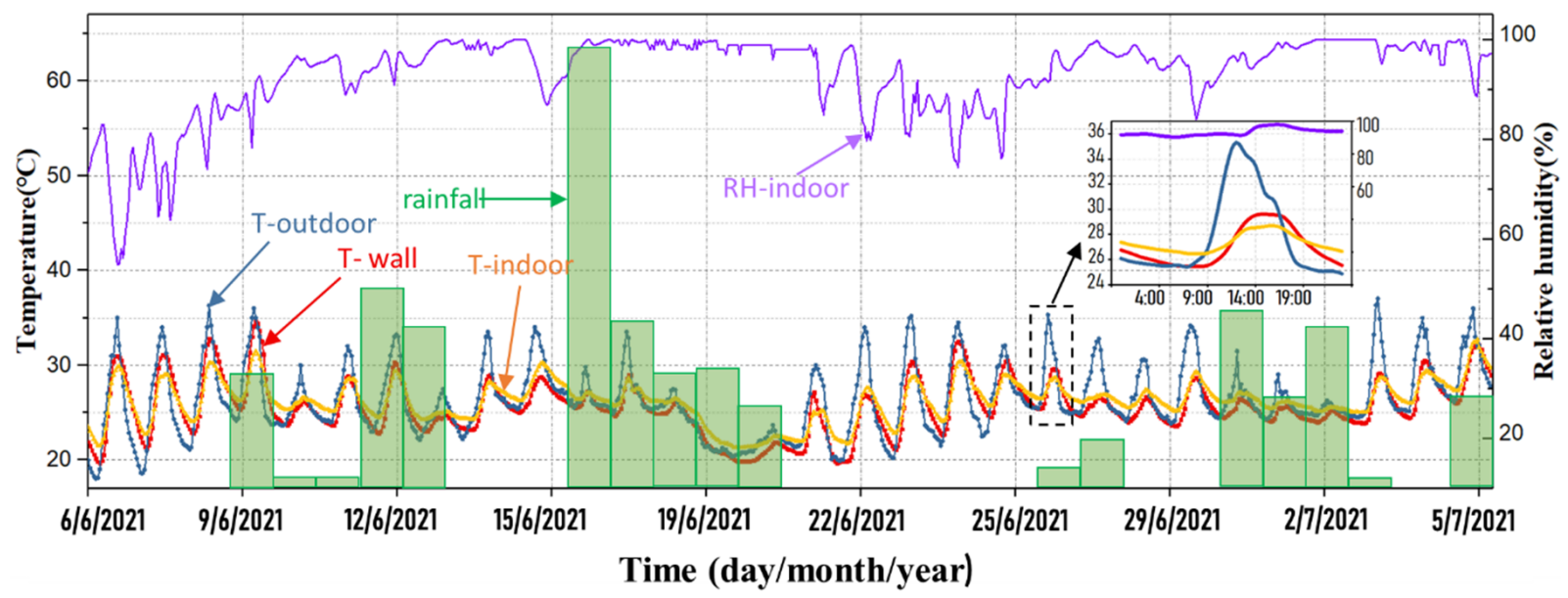

Figure 7. Temperature and relative humidity inside and outside the stone house (6 June 2021-5 July 2021). 
In this period, as we can see from the graph, there were 17 rainy days, and the indoor humidity exceeded $80 \%$ RH most time, and when continuous rainy days occurred, the humidity reached $100 \% \mathrm{RH}$. During the monitoring period, the temperature fluctuations range of the air in and out of the stone chamber were $20^{\circ} \mathrm{C}\left(18-38^{\circ} \mathrm{C}\right)$, and $12{ }^{\circ} \mathrm{C}\left(22-34^{\circ} \mathrm{C}\right)$, respectively. The temperature fluctuation of the inner wall surface was $15^{\circ} \mathrm{C}\left(20-35^{\circ} \mathrm{C}\right)$.

Figure 7 showed an example date of 26 June 2021. From 00:00 to 6:00 a.m., both air and wall temperatures showed a slow downward trend, during which the temperature indoors was higher than the wall surface and the outside temperature. Due to the solar radiation, the temperature at three points gradually increased after 6:00 a.m., especially after 9:00 a.m.; the temperature of outdoor air rose rapidly as well as the temperature of the wall surface, while the temperature of the indoors rose slowly. At about 1:00 p.m., the temperature of the outside air dropped rapidly, a phenomenon that might be related to the weakened solar radiation caused by rainfall. At the same time, the temperature of the inside atmosphere and wall surface reached a maximum. After $6: 00 \mathrm{pm}$, the wall surface and the indoor air temperature both began to drop, but the wall surface temperature dropped more quickly, which caused the wall surface temperature to be lower than the indoor temperature about $2 \mathrm{~h}$ later. The wall surface temperature was lower than the indoor air temperature during these $24 \mathrm{~h}$ except from 1:00 to 8:00 pm, which undoubtedly created favorable conditions for the generation of condensation, considering the relative humidity of the indoor air was maintained at $90 \% \mathrm{RH}$ all the time.

In comparing the data of T3 (installed on the south side) and T4 (installed on the north side), there are differences in the temperature of the wall surface at different locations within the room. Figure 8 showed that the surface temperature of the south side wall changed dramatically, with a maximum temperature exceeding $45^{\circ} \mathrm{C}$, while the temperature of the north side wall fluctuated slowly. The temperature on the south side of the stone house was generally higher than that on the north side, which indicated that condensation water was more likely to occur on the north wall. Changes in relative humidity of the wall also confirmed these results, as the humidity on the south side was lower than that on the north side.

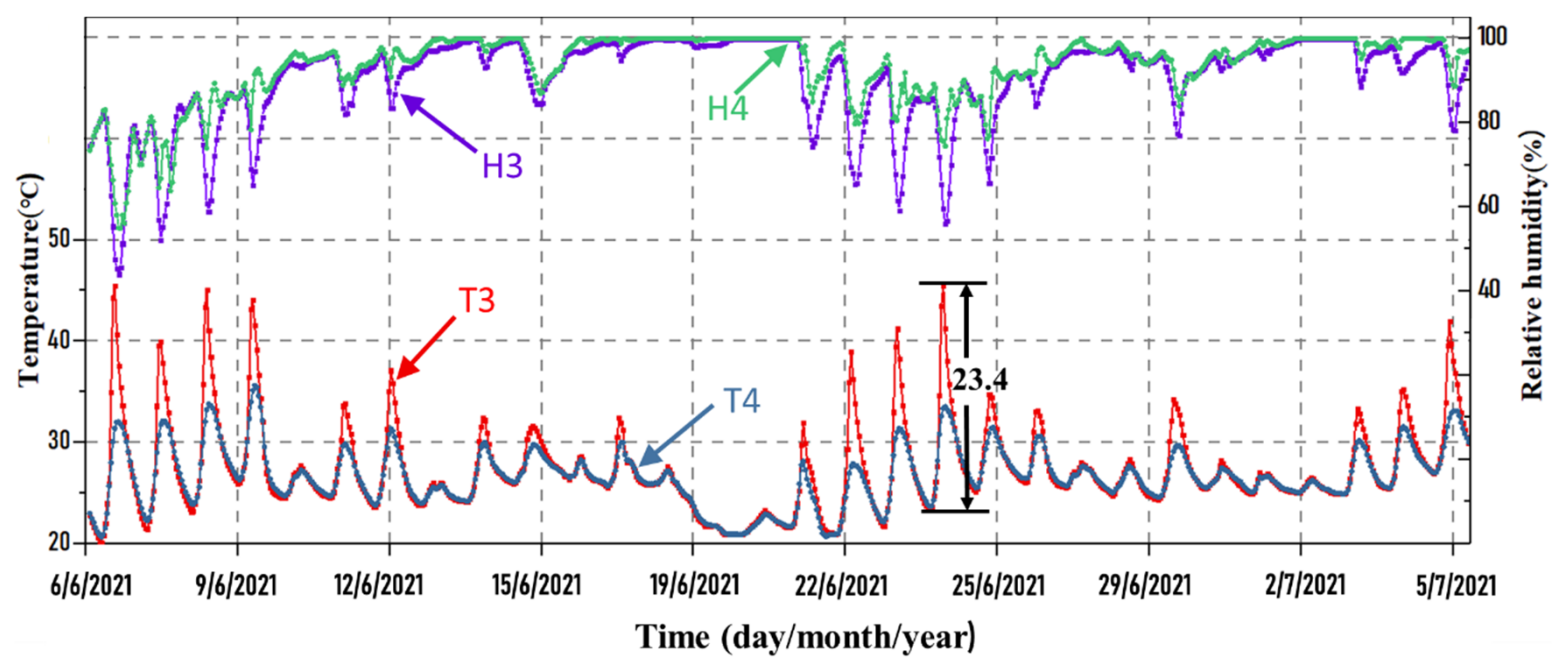

Figure 8. Temperature and relative humidity of the wall surface in the house (6 June 2021-5 July 2021).

\subsection{Condensate Water}

\subsubsection{Dew Point Temperature}

To produce condensed water, the vapor pressure of the humid air must reach saturation, and the temperature at this point is called the dew point temperature. The formation of condensed water on the inner wall of the stone house can be explained as wet air with a high temperature coming into contact with a wall below the dew point, and the vapor pressure of humid air reaches saturation, which causes excess water molecules in the air to 
condense on the wall. In other words, whether condensed water will be generated depends on whether the wall surface temperature is lower than the dew point temperature. Three formulas were used to calculate the dew point temperature in this study:

The first step was to calculate the saturated vapor pressure of water by Formula (1).

$$
e=6.1121 \exp \left[\frac{A \bullet t}{t+273.15-B+C \bullet(t+273.15)^{2}}\right]
$$

where: $e$ is the saturated vapor pressure, the unit of which is mbar, $t$ is the air temperature, the unit of which is ${ }^{\circ} \mathrm{C}$. Since the temperature in this study was always greater than zero, the constants $A, B$, and $C$ were taken as $20.013,16.286$, and $2.492 \times 10^{-4}$, respectively.

In order to determine the steam vapor partial pressure in wet air, saturated vapor pressure was divided by relative humidity, which was calculated as follows:

$$
e_{w}=e \times E
$$

where: $e_{w}$ is the partial pressures of water vapor, the unit of which is mbar; $E$ is the relative humidity, the unit of which is $\%$; then, the dew point temperature, abbreviated as $t_{d}$, was calculated by Formula (3):

$$
t_{d}=\frac{243.12 \ln \left(e_{w} / 611.12\right)}{17.62-\ln \left(e_{w} / 611.12\right)}
$$

In Figure 9, the calculated dew point temperature was used to subtract the wall surface temperatures measured at points $\mathrm{T} 3$ and $\mathrm{T} 4$, and the results were represented in a histogram. In the event of a negative difference, the wall surface temperature will be lower than the dew point temperature, and condensation will occur. As can be seen from the figure, there has been more condensate generated on the north side of the wall (blue in the picture) than on the south side (orange in the picture), and according to statistics, more than two-thirds of the days have produced condensate on the north side of the wall during this period (6 June 2021-5 July 2021). In addition, for one specific day, condensation mainly occurred before and after daybreak.

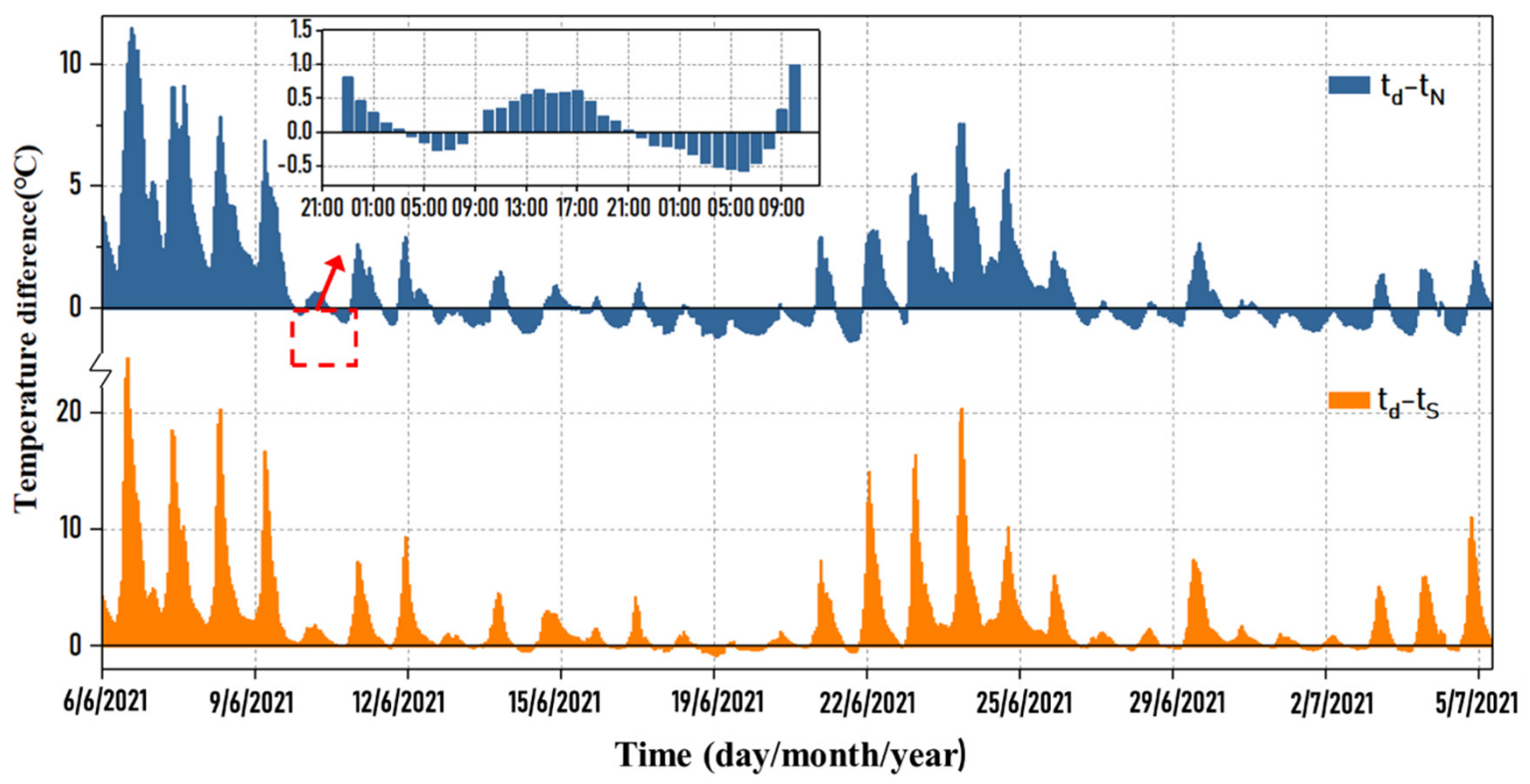

Figure 9. Difference between the dew point temperature and the wall surface temperature.

\subsubsection{Condensate Water Calculation}

In this study, the rate of condensation generation was calculated in order to quantify the amount of condensation on the stone chamber's walls. When wet air at a high tempera- 
ture encounters a wall surface at a low temperature, condensate is formed (see Figure 10). The condensate water can be calculated by Formula (4).

$$
W=G \times\left(d_{1}-d_{2}\right)
$$

where $G$ is the mass of air near the wall surface per hour, and its unit is $\mathrm{kg} / \mathrm{h} . d_{1}$ and $d_{2}$ are the humidity ratio of wet air before and after condensation, respectively, and its unit is $\mathrm{g} / \mathrm{kg}$.

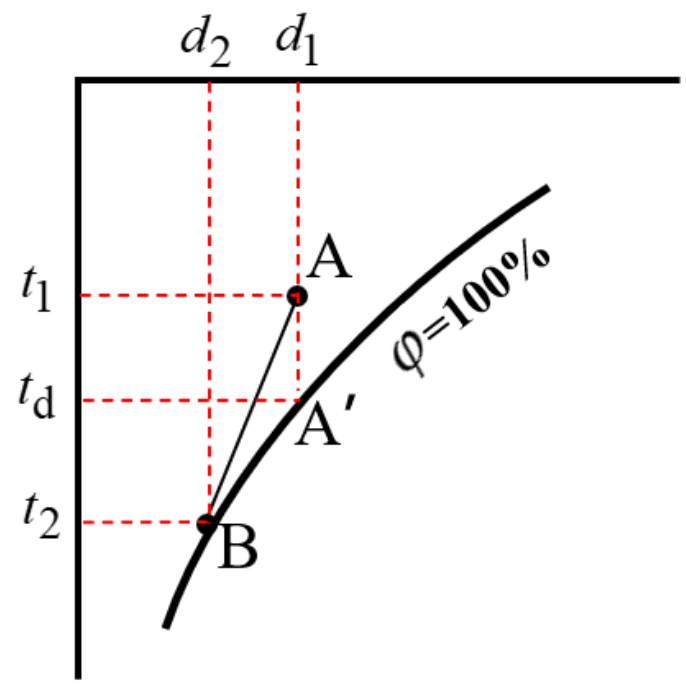

Figure 10. Schematic diagram of the condensation process.

It can be seen from the enthalpy-humidity diagram that the humidity ratio of point $\mathrm{A}$ is equal to that of point $\mathrm{A}^{\prime}$, while point $\mathrm{A}^{\prime}\left(t_{d}, d_{1}\right)$ and point $\mathrm{B}\left(t_{2}, d_{2}\right)$ are both on the curve with a relative humidity of $100 \%$. So, the humidity ratio $d_{1}$ and $d_{2}$ can be calculated through the dew point temperature $\left(t_{d}\right)$ and the wall surface temperature $\left(t_{2}\right)$ based on the functional relationship between the temperature and humidity ratio. The data on the enthalpy-humidity diagram could be fitted to a polynomial whose math expression is Equation (5). Since the coefficient of determination reached 0.9999 (see Figure 11), this formula can be used to estimate the humidity ratio in the air.

$$
d=0.0007 t^{3}-0.0127 t^{2}+0.5598 t+2.9259
$$

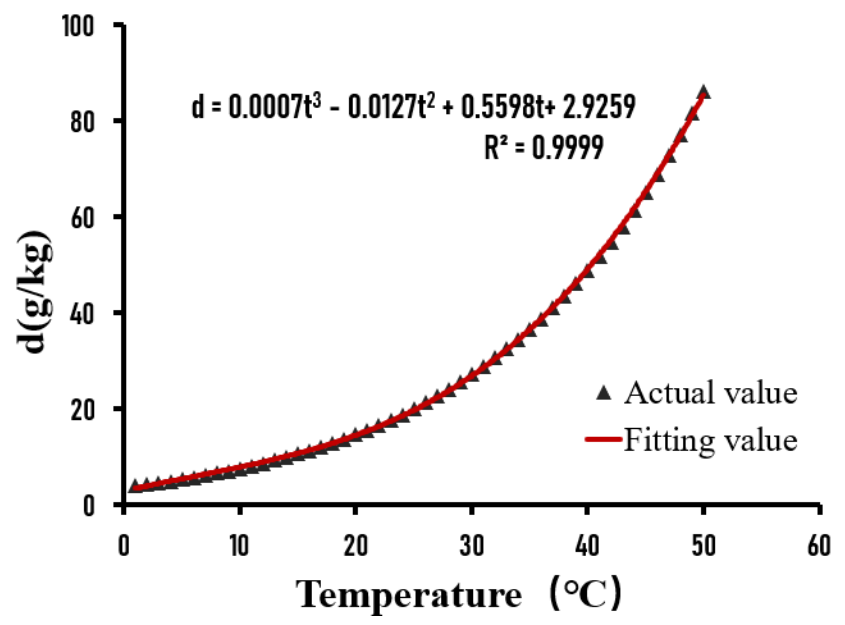

Figure 11. Functional relationship between temperature and the humidity ratio. 
Based on the assumption that the mass of wet air near the surface of the wall was $1 \mathrm{~kg}$ per hour, we can calculate the mass of condensate water generated, as shown in Figure 12. Since the stone house in this study was similar to the caves of the Mogao Grottoes studied by Wang [40], both of which were single-sided openings and relied on natural ventilation for air exchange so the air exchange rate of the stone house in this study was about $4 \mathrm{~h}^{-1}$, the density of wet air can be selected as $1.2 \mathrm{~kg} / \mathrm{m}^{3}$. Since the total volume of this house was about $80 \mathrm{~m}^{3}$, then the mass of condensate water generated on the wall surface was about $460 \mathrm{~g} / \mathrm{h}$.

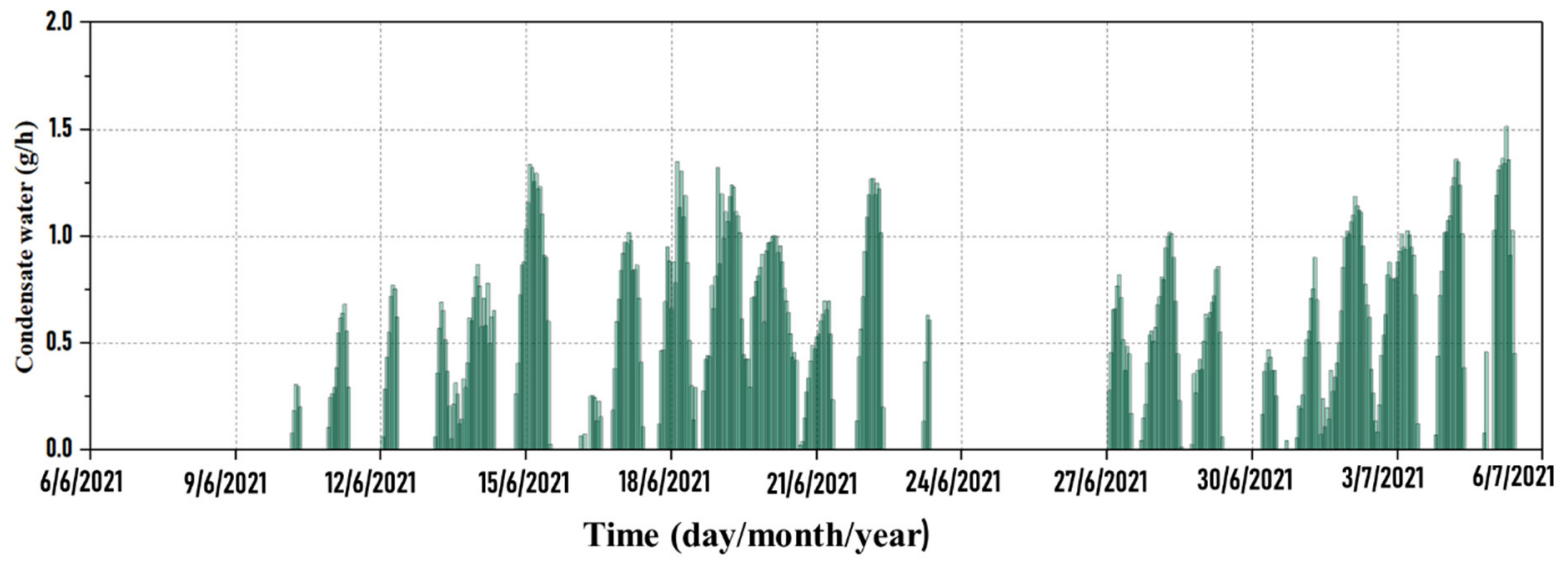

Figure 12. Generation rate of condensate rate on the wall surface in the stone house.

\subsection{Discussion}

The stone house in this paper was in a very poor state of preservation, even though it was built only 100 years ago. A serious situation was caused by the rock, the preservation method, and the microclimate around the house.

Mineralogical and petrographic analysis confirmed that the stone used to build this house is tuff, which has a porosity of $26 \%$ when fresh, but $39 \%$ when weathered. Its water absorption by weight can reach $15 \%$, which shows that it is sensitive to water. In this study, the destructive effects of water are not only erosion and dissolution, but also salt crystallization caused by water. Under the influence of water, soluble salts inside the rock may dissolve, migrate, and crystallize, causing another expansion force. Multiple destructive forces act as a multitude of tiny jacks, causing the rock's surface layer to bulge and then fall off $[41,42]$.

The field disease investigation results show that the weathering degree of the inner wall of the stone house is higher than that of the outer side. Considering that the main source of water in the house is condensate rather than rain, it shows that a large amount of condensate has been produced on the inner wall. As we can see in Figure 1, there is only one grille with an area of about $2 \mathrm{~m}^{2}$ on the east side of the house which could allow airflow. According to our monitoring results (Figure 7), bad air circulation causes a significant temperature difference between indoors and outdoors, especially at night, when the temperature of the inner is higher than the outer surface. Due to such conditions, when it comes to the rainy season, condensation is easy to form because of the high humidity. In addition, with continuous weathering, many small particles form on the surface of the wall, which then form condensate nodules and facilitate the formation of condensate. At the same time, due to Kelvin's effect [30], reduced pressure in rock pores promotes condensate generation, and the presence of soluble salt accumulation on the wall surface also accelerates the formation of condensation according to Raoult's law [43,44].

The destructive effect of temperature difference stress on the stone house, especially the wall on the south side, cannot be ignored in addition to the condensates. In Figure 7 , the temperature difference between the outside air and the wall surface is around $5{ }^{\circ} \mathrm{C}$, while in Figure 8, the difference can reach $26^{\circ} \mathrm{C}$. Tuff rocks have thermal expansion values 
between $0.7 \mathrm{~mm} / \mathrm{m}$ and $-0.5 \mathrm{~mm} / \mathrm{m}$, according to laboratory tests. The thermal expansion coefficients vary from $10.1\left(10^{-6} / \mathrm{K}\right)$ to $-7.2\left(10^{-6} / \mathrm{K}\right)[45]$. According to the research results of Shi and Zhang [46], such a large temperature difference will generate a maximum of $2 \mathrm{MPa}$ of tensile stress inside the tuff stone, which leads to cracks in the rock, and then develops into warping and falling off.

\section{Conclusions}

In this study, a detailed deterioration investigation and environmental monitoring have been conducted on a stone house with a history of 100 years, and drawn the following conclusions:

(1) Water is an important reason for the rapid deterioration of tuff. Its destructive effects are not only scouring and dissolution, but also salt crystallization. Their joint action causes the rock surface to fall off and pulverize;

(2) In humid and rainy areas, if the air exchange is poor between the indoors and the outdoors, there will be a significant temperature difference between the air and the wall surface, which will form condensation on the inner wall, and the time of condensate generation is mainly from night to early morning;

(3) As a result of the different intensity of solar radiation, condensation is more likely to form on the north side, where sunlight is not directly available, as it has a low average temperature and little fluctuation, which favors the formation of condensation on the wall surface. By contrast, on the south side of the house, the destructive effect of the temperature difference cannot be ignored.

Author Contributions: Field investigation, Y.W. and J.S.; Data processing, Y.W. and J.Z.; Funding acquisition, J.S. and B.Z.; Project administration, J.S. and B.Z.; Writing-original draft, Y.W.; Writing-review \& editing, J.S. and B.Z. All authors have read and agreed to the published version of the manuscript.

Funding: This work was funded by The Conservation Science and Technology Project of Zhejiang Provincial Administration of Cultural Heritage (Grant Number 2021020).

Institutional Review Board Statement: Not applicable.

Informed Consent Statement: Not applicable.

Data Availability Statement: The data in this paper are given in the tables and figures within the manuscript.

Conflicts of Interest: The authors declare no conflict of interest.

\section{References}

1. Winkler, E.M. Decay of stone. Stud. Conserv. 1971, 16 (Suppl. S1), 1-14. [CrossRef]

2. Jones, M.S.; Wakefield, R.D. Aspects of Stone Weathering, Decay and Conservation. In Proceedings of the 1997 Stone Weathering and Atmospheric Pollution Network Conference (SWAPNET'97), Aberdeen, UK, 15-17 May 1997.

3. Vacchiano, C.D.; Incarnato, L.; Scarfato, P.; Acierno, D. Conservation of tuff-stone with polymeric resins. Constr. Build. Mater. 2008, 22, 855-865. [CrossRef]

4. Çelik, M.Y.; Ergül, A. The influence of the water saturation on the strength of volcanic tuffs used as building stones. Environ. Earth Sci. 2015, 74, 3223-3239. [CrossRef]

5. Wedekind, W.; López-Doncel, R.; Dohrmann, R.; Kocher, M.; Siegesmund, S. Weathering of volcanic tuff rocks caused by moisture expansion, Environ. Earth Sci. 2013, 69, 1203-1224. [CrossRef]

6. Alves, C.; Figueiredo, C.A.M.; Sanjurjo-Sánchez, J.; Hernández, A.C. Effects of Water on Natural Stone in the Built Environment-A Review. Geosciences 2021, 11, 459. [CrossRef]

7. Pötzl, C.; Siegesmund, S.; López-Doncel, R.; Dohrmann, R. Key parameters of volcanic tuffs used as building stone: A statistical approach. Environ. Earth Sci. 2021, 81, 10. [CrossRef]

8. Zhou, M.; Li, J.; Luo, Z.; Sun, J.; Xu, F.; Jiang, Q.; Deng, H. Impact of water-rock interaction on the pore structures of red-bed soft rock. Sci. Rep. 2021, 11, 7398. [CrossRef]

9. Ren, F.; Fang, T.; Cheng, X. Study on rock damage and failure depth under particle water-jet coupling impact. Int. J. Impact Eng. 2020, 139, 103504. [CrossRef] 
10. Eyssautier-Chuine, S.; Marin, B.; Thomachot-Schneider, C.; Fronteau, G.; Schneider, A.; Gibeaux, S.; Vazquez, P. Simulation of acid rain weathering effect on natural and artificial carbonate stones. Environ. Earth Sci. 2016, 75, 748. [CrossRef]

11. Livingston, R.A. Acid rain attack on outdoor sculpture in perspective. Atmos. Environ. 2016, 146, 332-345. [CrossRef]

12. Yang, X.; Wang, J.; Hou, D.; Zhu, C.; He, M. Effect of Dry-Wet Cycling on the Mechanical Properties of Rocks: A Laboratory-Scale Experimental Study. Processes 2018, 6, 199. [CrossRef]

13. İnce, İ. Relationship Between Capillary Water Absorption Value, Capillary Water Absorption Speed, and Capillary Rise Height in Pyroclastic Rocks. Min. Metall. Explor. 2021, 38, 841-853. [CrossRef]

14. Warscheid, T.; Braams, J. Biodeterioration of stone: A review. Int. Biodeter. Biodegr. 2000, 46, 343-368. [CrossRef]

15. Liu, X.; Koestler, R.J.; Warscheid, T.; Katayama, Y.; Gu, J. Microbial deterioration and sustainable conservation of stone monuments and buildings. Nat. Sustain. 2020, 3, 991-1004. [CrossRef]

16. Salvatici, T.; Calandra, S.; Centauro, I.; Pecchioni, E.; Garzonio, C.A. Monitoring and Evaluation of Sandstone Decay Adopting Non-Destructive Techniques: On-Site Application on Building Stones. Heritage 2020, 3, 1287-1301. [CrossRef]

17. Estefania, O.E.; Jesus, P.M.; Raudel, P.C.; Alfonso, L.R. In situ and nondestructive characterization of mechanical properties of heritage stone masonry. Environ. Earth Sci. 2018, 77, 281-286. [CrossRef]

18. Martinho, E.; Dionísio, A. Main geophysical techniques used for non-destructive evaluation in cultural built heritage: A review. J. Geophys. Eng. 2014, 11, 53001. [CrossRef]

19. Wu, Y.; Li, Q.; Tong, H.; He, Z.; Qu, J.; Zhang, B. Monitoring the Deterioration of Masonry Relics at a UNESCO World Heritage Site. KSCE J. Civ. Eng. 2021, 25, 3097-3106. [CrossRef]

20. Blocken, B.; Derome, D.; Carmeliet, J. Rainwater runoff from building facades: A review. Build. Environ. 2013, 60, 339-361. [CrossRef]

21. Patil, S.M.; Kasthurba, A.K.; Patil, M.V. Characterization and Assessment of Stone Deterioration on Heritage Buildings. Case Stud. Constr. Mater. 2021, 15, e00696. [CrossRef]

22. Figueiredo, C.; Alves, C. Principal Components Analysis (PCA) of Monument Stone Decay by Rainwater: A Case Study of "Basílica da Estrela" Church, Portugal. Proceedings 2018, 2, 560. [CrossRef]

23. Li, H.; Wang, W.; Zhan, H.; Qiu, F.; Guo, Q.; Zhang, G. Water in the Mogao Grottoes, China: Where it comes from and how it is driven. J. Arid Land. 2015, 7,37-45. [CrossRef]

24. Zhang, J.; Huang, J.; Liu, J.; Jiang, S.; Li, L.; Shao, M. Surface weathering characteristics and degree of Niche of Sakyamuni Entering Nirvana at Dazu Rock Carvings, China. Bull. Eng. Geol. Environ. 2019, 78, 3891-3899. [CrossRef]

25. Fang, S.; Zhang, B.; Zhang, K. The long-term monitoring and evaluation of cement-based grout used to govern the water seepage of karst caves in China. Herit. Sci. 2020, 8, 50. [CrossRef]

26. Varas-Muriel, M.J.; Fort, R. Microclimatic monitoring in an historic church fitted with modern heating: Implications for the preventive conservation of its cultural heritage. Build. Environ. 2018, 145, 290-307. [CrossRef]

27. Antunes, A.C.; Coroado, J.; Boaventura, D.; Rocha, F. The environmental factors impact on the conservation of an historic marine quay-A baseline study. Environ. Sci. Pollut. Res. 2015, 22, 9563-9569. [CrossRef]

28. Guo, P.; Li, Y.; Xing, H. Study on the control of condensed water on the frescos in Two Southern Tang Dynasty cemeteries. Sci. Conserv. Archaeol. 2015, 27 (Supplement S1), 22-26. [CrossRef]

29. Liñán, C.; Benavente, J.; del Rosal, Y.; Vadillo, I.; Ojeda, L.; Carrasco, F. Condensation water in heritage touristic caves: Isotopic and hydrochemical data and a new approach for its quantification through image analysis. Hydrol. Process. 2021, 35, e14083. [CrossRef]

30. Camuffo, D.; Giorio, R. Quantitative Evaluation of Water Deposited By Dew on Monuments. Bound.-Lay. Meteorol. 2003, 107, 655-672. [CrossRef]

31. Yang, G.; Fang, Y. Study on disease investigation and quantitative testing of condensation water at Longmen Grottoes. Study Cave Temples 2018, 2018, 353-383. (In Chinese)

32. Zheng, L.L.; Fu, X.Z. Study on mechanism of water condensation and field experiments of Thousand-Hand Guanyin in Dazu Rock Carvings. IOP Conf. Ser. Earth Environ. Sci. 2018, 186, 12007. [CrossRef]

33. Ding, Y.; Liang, P.; Liu, Y.; Zhang, Y. Multiscale Variability of Meiyu and Its Prediction: A New Review. J. Geophys. Res. Atmos. 2020, 125, 2019JD031496. [CrossRef]

34. Tong, M.; Zheng, Z.; Fu, Q. Characteristics of Meiyu Seen From Multiple Observational Analyses and Reanalyses. Earth Space Sci. 2021, 8, e2021EA001647. [CrossRef]

35. ICOMOS-ISCS. Illustrated Glossary on Stone Deterioration Patterns. Available online: https://iscs.icomos.org/glossary.html (accessed on 1 November 2021).

36. Liu, R.Z.; Zhang, B.J.; Zhang, H.; Shi, M.F. Deterioration of Yungang Grottoes: Diagnosis and research. J. Cult. Herit. 2011, 12, 494-499. [CrossRef]

37. Li, Y.; Xia, C.; Wu, R.; Ma, Y.; Mu, B.; Wang, T.; Petropoulos, E.; Hokoi, S. Role of the urban plant environment in the sustainable protection of an ancient city wall. Build. Environ. 2021, 187, 107405. [CrossRef]

38. İnce, İ; Bozdağ, A. An investigation on sample size in Leeb hardness test and prediction of some index properties of magmatic rocks. Arab. J. Geosci. 2021, 14, 182. [CrossRef]

39. Zhejiang Provincial Meteorological Bureau. Available online: http://zj.cma.gov.cn/zwxx/qxyw/202107/t20210705_3492304.html (accessed on 1 November 2021). 
40. Wang, J.; Yan, Z.; Wang, X.; Zhang, Z.; Shang, R.; Bi, W. Experimental research on mechanical ventilation system for Cave 328 in Mogao Grottoes, Dunhuang, China. Energ. Build. 2016, 130, 692-696. [CrossRef]

41. Özşen, H.; Bozdağ, A.; İnce, İ. Effect of salt crystallization on weathering of pyroclastic rocks from Cappadocia, Turkey. Arab. J. Geosci. 2017, 10, 258. [CrossRef]

42. Deniz, B.E.; Topal, T. A new durability assessment method of the tuffs used in some historical buildings of Cappadocia (Turkey). Environ. Earth Sci. 2021, 80, 266. [CrossRef]

43. Vilbaste, M.; Heinonen, M.; Saks, O.; Leito, I. The effect of water contamination on the dew-point temperature scale realization with humidity generators. Metrologia 2013, 50, 329. [CrossRef]

44. Zhang, W.; Zhang, K.; Zhang, Y. Study on the effect of Raoul effect on dew point and its compensation method. In Proceedings of the 7th National Conference on Humidity and Moisture, Nanjing, China, 9-13 November 1998. (In Chinese)

45. López-Doncel, R.; Wedekind, W.; Aguillón-Robles, A.; Dohrmann, R.; Molina-Maldonado, S.; Leiser, T.; Wittenborn, A.; Siegesmund, S. Thermal expansion on volcanic tuff rocks used as building stones: Examples from Mexico. Environ. Earth Sci. 2018, 77, 338. [CrossRef]

46. Shi, Z.; Zhang, L. Deformation and failure mechanism of tuff under heating. In Proceedings of the 4th National Youth Symposium on Rock Mechanics and Engineering, Zhengzhou, China, 1 June 1997. (In Chinese) 